\title{
LA CONTRIBUCIÓN DEL CLERO CASTELLANO A LOS SERVICIOS DE MILLONES
}

\author{
Lucía CARPINTERO AGUADO
}

Universidad Autónoma de Madrid

Las páginas que a continuación presentamos forman parte de un estudio mucho más amplio en el que se aborda el examen cualitativo de la contribución de la Iglesia castellana a las cargas públicas'. Dicha labor se llevó a cabo mediante el análisis de una institución eclesial cuya función consistía en canalizar y, en su caso, fiscalizar las ayudas económicas que el clero prestaba a la corona: Ia Congregación de las Iglesias de Castilla y León. Con este apelativo se denomina el organismo corporativo que aglutina las treinta y seis diócesis del reino, con el doble abjetivo de efectuar una defensa mancomunada de los privilegios inherentes a su estado y de negociar con la corona las obligaciones fiscales del estamento eclesiástico. El concepto de Congregación se define mediante la coexistencia de dos elementos fundamentales: la celebración periódica de asambleas integradas por delegados de los cabildos-catedrales, y la realidad de la confraternidad capituiar -materializada en el carácter de una institución concebida como Cuerpo Comín del Clero-. El empleo de tal término se justifica en la medida que no nos limitemos a señalar una reunion coyuntural de las Iglesias, sino también un contenido: la forma especifica de organización del Clero en una Comunidad que actuaba como garante de las prerrogativas de su estamento.

Inicialmente, las Congregaciones Generales del Clero se limitaron a ajustar las concesiones de Subsidio y Excusado ${ }^{2}$ mediante un sistema de concordias que regulaba las condiciones de colectación y posterior percepción por parte de la corona del producto de dichas Gracias. Ahora bien, el organismo adquirió un protagonismo creciente a medida que se multiplicaron los gravamenes cargados sobre el estamento eclesiástico y que se conculcaron sus inmunidades tributarias. Cabe afirmar que la Congregación evolucionó de forma paralela a las fiscalidades de la corona y del Reino. Sin embargo, es preciso subrayar que las Iglesias sólo fueron capaces de 
limitar -si bien con carácter puntual y coyuntural- los impuestos privativos de su estado. En lo que respecta a los tributos creados por las Cortes, los cabildos, inermes ante las regalias de la corona, únicamente pudieron elevar una protesta sostenida. En determinadas circunstancias, los clamores del clero alcanzaron extremos tales, que los monarcas se vieron obligados a restablecer sus privilegios fiscales al menos en los límites de la ficción legal.

Consideramos ineludible denotar el carácter de sintesis del presente artículo dada su imbricación en un tema de naturaleza compleja, así como la obligada reducción del mismo por razones editoriales.

Las relaciones económicas entre la Iglesia y el Estado es un tema trascendental que la historiografía ha obviado. Sólo algunos autores hacen referencia a él dentro del marco generalizado de la Hacienda de los Austrias. No obstante, las ayudas fiscales del Clero -y de manera especial las introducidas a raiz del desastre de la Invencible- constituyen un instrumento de extraordinario valor a la hora de evaluar el papel político de la Iglesia castellano-leonesa. Los servicios de millones fueron un vehículo de transgresión sistemática de las libertades eclesiásticas. Una vía eficaz para someter al clero a una suerte de servidumbre impositiva. La creación de los millones introducirá sensibles cambios en la forma en que hasta entonces dicho estamento había coadyuvado al mantenimiento del Estado. A partir de 1590, fecha en que se aprobó el primer servicio de millones, es preciso distinguir entre la Hacienda real y la del Reino. Se configuraba así una segunda fiscalidad paralela a la de la corona que, al anular las exenciones contributivas, introducirá la tributación de los eclesiásticos como vasallos, convirtiendo en pechera una institución que por si misma gozaba de capacidad fiscal. El carácter de tales imposiciones sacudió los fundamentos de la inmunidad de la Iglesia, cuyos ministros -gravados y humilladosvertieron un reguero de quejas que marcó las relaciones económicas entre el clero y el Estado a lo largo de toda la centuria.

\section{Surgimiento y consolidación del nuevo sistema fiscal (1590-1638)}

En abril de 1590 se firmó la primera escritura estableciendo un servicio de $\&$ millones de ducados, cantidad que el Reino se comprometía a pagar en un plazo de seis años. Su recaudación se llevaría a efecto mediante el sistema de repartimiento. A cada provincia se cargó el 1 por 100 de lo que las Iglesias de su demarcación contribuían en concepto de Subsidio ${ }^{4}$. Para poder extender al clero dados sus privilegios fiscales- la obligación de contribuir se solicitó en Roma la licencia necesaria. Gregorio XIV expidió, en 16 de agosto de 1591, el breve que permitía la contribución del estado eclesiástico en el servicio. Entre tanto, en algunas ciudades, se comenzó a cobrar el tributo a los eclesiásticos. Fue entonces cuando surgieron las primeras protestas y actuaciones individuales de ciertos obispos. Pero, en general, los prelados disimularon su repugnancia hacia los Millones y permitieron 
su cobranza. La tolerancia del episcopado fue criticada con dureza por el clero capitular, que consideraba la defensa de la inmunidad ejercicio propio del ministerio pastorals.

En 1601, el Reino acordó la concesión de un servicio de 18 millones asumiendo todas las competencias que hasta entonces ejercieran las ciudades. El medio de contribución elegido fue la sisa, o detracción en la cantidad del artículo vendido. Las especies gravadas fueron el vino y el aceite. Mas cuando se comprobó que el rendimiento de las mismas resultaba insuficiente para reunir la cantidad comprometida se amplió el número de contribuyentes y artículos gravados. Poco después, la sisa del vino se extendió al vinagre y aguapié. Asimismo, la obligación de contribuir comprendería a "todos y cualesquiera consumidores o bebedores y gastadores de los dichos alimentos, aunque sean verdaderos cosecheros, arrendadores, o lo tengan de diezmos o rentas, o sacados de uva o aceitunas que hayan habido por compra o venta", es decir, a los eclesiásticos y nobles, hasta entonces exentos por no figurar como compradores del vino y aceite que recibían en concepto de rentas. A continuación, el gravamen se extendió a la carne, artículo sobre el cual se cargó un verdadero impuesto, consistente en un maravedí por libra o un real por cabeza de carnero o cabra vendida en los rastros ${ }^{6}$. Clemente VIII, por sucesivos breves expedidos en 1601, 1603 y 1604, permitió la contribución del clero en el nuevo servicio, admitiendo también el pago de las sisas añadidas y prorrogando el período inicial de tributación -seis años- por un trienio. Sin embargo, los breves de extensión recortaban el carácter general de la obligación establecido por el Reino, pues declaraban que "las personas Eclesiásticas, Seculares y Regulares, y los Monasterios, Colegios, Conventos y Cabildos estén obligados, y puedan asimismo en lo venidero ser apremiados, y compelidos como los Legos en todo, y por todo. a pagar la expresada Gabela, o Sisa, en cuanto a las especies de cosas, (pero no en cuanto a aquellas cosas que consumen para sus propios usos, y los de sus familias; de suerte, que en lo que toca a los dichos usos de ellos, y de sus familias, queden enteramente inmunes, $y$ exentos) ${ }^{m 7}$.

La licencia pontificia suscitó la oposición de los cabildos, que organizaron una defensa mancomunada de sus privilegios. El clero tenía la absoluta certeza de que, en adelante, la exacción del nuevo impuesto superaría el monto del Subsidio y Excusado; y por otra parte, afirmaba que el pontífice había supuesto la intervención del estamento eclesiástico en el establecimiento del mismo. Consideraban los cabildos que un negocio tan relevante, que atañía a las libertades de la Iglesia, habría requerido, según disponían los cánones de los concilios y opinaban los más eminentes teólogos, la consulta de los prelados. Era cierto que, potencialmente, el gravamen de especies como el vino y el aceite tenía que afectar más a los eclesiásticos, que eran los mayores consumidores de dichos artículos. Además, alegaban éstos que se veian obligados a pagar sisa tanto de los productos que consumian, como de las rentas que disfrutaban, por cuanto los arrendatarios abonaban sus cánones practicados los descuentos de la sisa que correspondía a los frutos cosechados. 
Pero no era Ía salvaguardia de la inmunidad real la única preocupación de las Iglesias. En el fondo existía un conflicto jurisdiccional, ya que la bula de 1601 contenía una claúsula que se prestaba a todo tipo de equivocos y excesos: "... y si fuere necesario, concedemos, que pueden ser apremiados y compelidos con oportunos remedios de derecho, $y$ de hecho, por los Cobradores de dichos servicios extraordinarios, o Subsidios, o de la Gabela, o Sisa, que con su motivo se impusiere...". Tal disposición promovia la intervención de las justicias seglares en la cobranza del servicio, lo cual fue interpretado por los cabildos como un agravamiento de la carga, puesto que representaba una violación tácita de la jurisdicción eclesiástica. El monarca se dirigió a las ciudades de voto en Cortes ordenando que serian los prelados quienes procediesen a la averiguación del vino y aceite que los eclesiásticos tuviesen en sus casas y bodegas. Sin embargo, tal disposición no debió tener cumplido efecto, puesto que una de las quejas que la Congregación de 1602 elevó al soberano fue precisamente sobre los registros de ambas especies, en los que continuaban actuando como árbitros los jueces seglares.

Por el mencionado breve de 1603, Clemente VIII anuló tan conflictiva claúsula. ordenando que "los Cobradores no puedan, ni deban compeler a los Eclesiásticos que lo rehusaren, por si mismos. u otros ministros seculares: sino valiéndose de la autoridad de los Ordinarios de los lugares, y ante ellos mismos: a quienes con estrecho precepto mandamos, que a cualquiera simple requerimiento de los dichos Cobradores, procedan de nuestra autoridad ejecutivamente (removida toda apelación) contra los Eclesiásticos que lo rehusaren, aunque sean regulares, y exentos, e inmediatamente sujetos a Nos, y a la Sede Apostólica". En adelante el castigo de los clérigos infractores quedaba a cargo de la jurisdicción eclesiástica. Las justicias seglares que apremiaran al clero al pago de las sisas incurririan en excomunión. Además el pontífice penaba con censuras tanto el hecho de cargar indebidamente a los eclesiásticos, como la negativa de éstos al cumplimiento de la imposición. Las disposiciones de Clemente VIII fueron confirmadas sucesivamente en todas las Letras Apostólicas relativas al servicio de Millones.

El servicio de 1601 sentó las bases de un sistema fiscal acorde a las necesidades bélicas de la Monarquía. En 1608 el Reino concedió un servicio de 17,5 millones de ducados por un plazo de siete años -que posteriormente se elevaría a nueve-, y cuya percepción había de comenzar en 1611 . En 1617 se acordó un nuevo servicio -18 millones- a percibir entre 1619 y $1628^{8}$. Paulo $\mathrm{V}$ no opuso objeción alguna al otorgamiento de la primera licencia solicitada para la contribución del clero, pero se mostró reticente cuando el monarca reiteró la petición. El exceso con que se usaba de tales concesiones excitaba los escrúpulos del pontífice, receloso por otra parte a causa de la desigualdad de trato observada con respecto a eclesiásticos y seglares pues, en definitiva, era la voluntad de estos últimos la dispensadora de tales servicios. No obstante, por breve de 8 de agosto de 1618, el papa Borghese accedía a la inclusión del clero en el servicio de los 18 milones por un sexenio (1619-1625). 
Los contenciosos que la Monarquía tenía pendientes en Europa en el período comprendido entre 1621 y 1628 obligaron al Reino a otorgar dos servicios sucesivos: uno de 12 millones (1626) y otro de 18 (1628). La licencia para la contribución del estado eclesiástico fue obtenida de Urbano VIII'. En noviembre del 1625 el mismo pontífice había prorrogado por tres años el período contributivo establecido por Paulo $\mathrm{V}$ en 1618.

El rendimiento del servicio concedido en 1619 no fue suficiente para reunir la cantidad señalada en el plazo de nueve años, motivo por el cual los ministros reales comenzaron a hacer diligencias para obtener del papa una nueva prórroga. $\mathrm{Al}$ mismo tiempo gestionaban la licencia necesaria para que el clero contribuyera en el primer ciento, impuesto que se había establecido como uno de los medios destinados a reunir el servicio de los 12 millones. Tales instancias suscitaron el recelo de las Iglesias y la primera oposición organizada del estamento contra los Millones. La figura fiscal con que se trataba de gravar al clero consistía en una elevación porcentual del tipo teórico de la tasa alcabalatoria. Dicho impuesto fue finalmente tomado en encabezamiento por el Reino a consecuencia de las numerosas reclamaciones que suscitó en el sector comercial, con la condición de que los eclesiásticos quedasen obligados a su pago. Semejante disposición había de provocar necesariamente la resistencia del clero, que estaba exento del pago de alcabalas tanto por los productos que recibía de sus arrendatarios en concepto de renta, como por los ingresos decimales ${ }^{16}$. Por otra parte, la justa indignación de la Congregación porque se continuaba la cobranza del antiguo tributo después de haber expirado la concesión apostólica, determinó la disposición de una serie de medidas encaminadas a resistir el pago de los 18 millones. Se ordenó a los cabildos la prosecución de pleitos en defensa de la inmunidad. Y se recomendó a Iglesias y prelados que solicitaran del papa un alivio de las cargas que soportaba el estamento. Entre tales disposiciones sobresalía una novedad: por vez primera el organismo asambleario se constituía en eje de las reclamaciones del clero castellano. Tanto la salvaguardia de las libertades de la Iglesia, como los litigios individuales que emprendiera cada diócesis, serian gobernados con carácter de negocio comín del estado eclesiástico. El monarca instó al episcopado a no tolerar contradicción alguna por parte del clero. Mas el temor a los dictámenes de la Santa Sede aconsejaba el empleo de procedimientos suaves con el fin de evitar los escándalos que ocasionaría una exacción no permitida. En Roma, la congregación de cardenales que estudiaba el asunto había dictaminado a favor de las Iglesias ${ }^{1 i}$. Entre tanto, la Asamblea del Clero comenzaba a hacer planteamientos susceptibles de desestabilizar el sistema fiscal castellano si los eclesiásticos eran obligados a tributar en contra de la voluntad del Romano pontífice: "... porque en todo tiempo se ha tenido por preciso el pedir nueva gracia a su Santidad, y esto mismo se haze con el Reyno, a que se deve mucho atender, porque V.M. nunca pide tributos sin cansa, y con todo no los impone sin el consentimiento de las Cortes, $y$ assi mucho menos se avran de imponer al Estado Eclesiastico estas contribuciones, a titulo de causa justa, particularmente que no se espera el consentimiento de las Iglesias. excluydos ya de las Cortes los Prelados, y quedarian gravadas por solo la 
concesion de los Procuradores seglares...". Por ello, la corona inició la búsqueda de procedimientos que permitieran mantener integra la apariencia de inmunidad a la vez que sus intereses quedaran plenamente satisfechos. Los ministros reales se comprometieron a dar refacción al clero por las cantidades indebidamente cobradas si no se obtenia breve de extensión. La aprobación de dicho medio conllevaba la suspensión de los pleitos entablados por los cabildos y la continuación de la cobranza de las sisas durante cuatro meses más, término en que el rey se obligaba a traer declaración apostólica sobre el alcance de la gracia otorgada en 1625.

Sin embargo, existían cortapisas que impedían a la Congregación tomar un acuerdo semejante. Tanto los cánones como los estatutos asamblearios limitaban la autoridad y la autonomía del organismo. En primer lugar, porque en la contribución de Millones concurrían los clérigos, las Iglesias y el Obispo por sí y como administrador de las Iglesias de su diócesis. Por dicho motivo era necesario el consentimiento del prelado, sin el cual todo acuerdo sería nulo. Por tanto la Congregación no podía pactar convenios con la corona por defecto de poder, pues los cánones disponian que cualquier acción del cabildo requería del consenso del obispo, y viceversa. En segundo lugar, por la propia naturaleza de la contribución, en la cual participaban clérigos e Iglesias non prout in universum, sed prout ut singuli. Luego cualquier convenio que se ajustase con el monarca exigía, bien el consentimiento universal del alto clero, o bien el beneplácito pontificio puesto que la autoridad apostólica podía compeler al clero al pago de tributos. Urbano VIII puso fin al conflicto por breve de 2 de junio de 1629, mediante el cual absolvía al monarca y a sus ministros de las censuras en que habian incurrido por haber cobrado las sisas sin concesión apostólica, ordenando asimismo que las cantidades percibidas indebidamente habian de descontarse de la parte que correspondiera pagar al estado eclesiástico en el nuevo servicio de los 18 millones. La licencia para dicha contribución había sido otorgada pocos días antes. Con objeto de evitar el solapamiento de los servicios de los 12 y los 18 millones, el papa ordenaba la exclusión del clero en el pago de los tributos establecidos para hacer frente al primero de ellos, o bien la restitución de los 60.000 ducados por cada año que el estamento eclesiástico satisficiera las dos contribuciones.

La entrada de Suecia en la guerra de los Treinta Años, y posteriormente la de Francia, motivaron la multiplicación de servicios concedidos por el Reino. Entre 1632 y 1635 las Cortes se vieron obligadas a otorgar un servicio de 24 millones resultado de la unión de los dos servicios que se venían cobrando desde seis años antes- (julio de 1632), otro de 2,5 millones (noviembre de 1632), y una ayuda de 600.000 ducados $(1634)^{12}$. Durante el quinquenio $1635-1640$ se iniciaba una nueva etapa en la política hacendística de Felipe IV, caracterizada por el paso a una economía de guerra, y por el drenaje cada vez más drástico de los recursos de la nación ${ }^{13}$. En 1635 las Cortes hubieron de votar un servicio de 9 millones en plata. A partir de entonces, la presión fiscal arrecia cada vez con mayor fuerza sobre todos los súbditos del reino. La fiscalidad castellana había alcanzado su perfil definitivo. 
Los tres servicios básicos serán prorrogados a cada vencimiento. Pero el cobro de tan cuantiosas concesiones exigió la creación de ensanches sobre las especies anteriormente gravadas, así como la introducción de nuevos arbitrios. Todo este complicado engranaje de servicios e impuestos indirectos deterioró las relaciones económicas del estamento eclesiástico con la corona. Con la particularidad de que, entre 1632 y 1644 , las dificultades se vieron agravadas por la hispanofobia de Urbano VIII, así como por el papel que asumieron la Monarquía hispana y el Papado en la coyuntura política internacional ${ }^{14}$.

El servicio de los 24 millones comenzó a exigirse del clero sin autorización pontificia. El monarca estimaba que la contribución del estamento eclesiástico estaba plenamente justificada por cuanto, sustancialmente, la concesión del Reino era una simple prorrogación de los dos servicios anteriores, para los cuales se había obtenido licencia papal. Pero la resistencia del clero, que comenzó a proveer censuras contra los corregidores, obligó a Felipe IV a pedir en Roma la autorización necesaria a fin de que el estado eclesiástico concurriese pacíficamente en la contribución. Las negociaciones que conducen a la consecución del breve constituyen uno de los episodios más arduos de la historia de los Millones. Mas, antes de adentrarnos en el análisis de las mismas, es preciso puntualizar una cuestión. La cantidad que los embajadores españoles pretendían obtener era inferior a la otorgada por el Reino. Ello se debía a que, desde 1629 , el pontífice había suspendido la contribución del clero en el servicio de los 12 millones. En consecuencia, el estamento eclesiástico únicamente podía ser incluido en el servicio de los 18 millones. Por otra parte, es preciso tener presente que ninguno de los dos servicios anteriores agotó el período por el que se había concedido. A fines de 1630 se suspendió la cobranza de ambos. El segundo de ellos fue sustituido por un impuesto general sobre la sals ${ }^{15}$. El posterior abandono del proyecto forzó al Reino a incrementar en un millón y medio el monto del servicio. Por tanto, el prorrateo de la suma global acordada por el Reino, para un período de seis años, suponía una derrama de 3.250 .000 ducados anuales, cantidad que ascendía durante el tiempo que el clero debía contribuir al pago de las sisas a 19,5 millones. Sin embargo, el estamento no quedó sujeto al pago de los 750.000 ducados suplementarios que las Cortes otorgaron a fin de alargar el servicio hasta 24 millones $^{16}$.

En contra de los temores del Consejo de Castilla, Urbano VIII no rehusó en ningún momento la concesión del breve. No obstante, la superposición de la décima de 600.000 ducados -otorgada en 5 de enero de 1632- y los Millones ofreció a Barberini la ocasión idónea para intentar someter a Felipe IV a una estrecha dependencia de la Silla Apostólica ${ }^{17}$. El mayor escollo de las negociaciones fue, en apariencia, de carácter formal. Estuvo representado por la inclusión en la bula de la claúsula denominada angmentum vero, mediante la cual el papa disponía que la cantidad en que excedía la nueva concesión al breve de 1629 debía aplicarse al auxilio del emperador. De un lado, comprometía al monarca a una suerte de pacto con Fernando II. De otro, sentaba un pernicioso precedente, pues la condicional era 
susceptible de una segunda lectura: "que el fin para conservar tan tenazmente esta clauisula es hacer a los reyes de España tributarios del Imperio". Pero no era ésta la única objeción que impedia la aceptación del breve. De la redacción del mismo se infería un reconocimiento tácito de la facultad del pontífice para disponer de los tributos que pagaban los vasallos del Rey Católico y, en consecuencia, su admisión habría determinado la sujeción de la corona a la Santa Sede. Los conflictos jurisdicionales que por entonces se libraban entre Roma y Madrid por cuestiones relacionadas con la política seguida en la nunciatura, así como la crisis de relaciones derivada de los contradictorios posicionamientos tomados por el monarca y el pontífice en la guerra de los Treinta Años, constituyeron un contexto idóneo para que el papa Barberini, pretextando su adhesión al emperador, intentara invalidar solapadamente los subsidios concedidos a Felipe IV. Ante la lluvia de protestas vertidas por los embajadores españoles y por el propio monarca contra la mencionada claúsula, Urbano VIII optó por ofrecer llanamente el breve de Millones siempre y cuando el monarca renunciara a la décima. La situación se agravó aún más cuando el marqués de Castel Rodrigo, a la sazón embajador extraordinario en Roma, observó que la bula expedida habia sufrido una notoria modificación. La conflictiva claúsula había dejado de ser un simple encargo para convertirse en una prescripción: además de revocarse el subsidio de los 600.000 ducados, el monarca quedaba expresamente obligado a aplicar parte de los ingresos de Millones a las guerras de Alemania. Aún existia otro agravante. El breve de restricción de la décima ataba de manos al soberano, puesto que estipulaba que su inobservancia repercutiria en la inmediata suspensión de la bula de Millones.

La actitud del pontífice encerraba móviles de carácter netamente político. En primer lugar, deteniendo los efectos concedidos a la corona española sobre el clero de Castilla, dilataba el apoyo económico de Felipe IV a su pariente. Por otra parte, conseguía disimular la tibieza y negligencia de que habia hecho gala en los asuntos de Alemania gracias a una "gran campaña propagandística" organizada con objeto de ponderar el celo aplicado a la defensa del emperador. El rechazo de Felipe IV movió al pontífice a idear una nueva estrategia. El breve de Millones se ofreció incluyendo la primitiva claúsula de recomendación creyendo que el rey no lo admitiría. Cuando Urbano VIII tuvo noticia de la aceptación regia, retiró la condicional y subrogó la última disposición. El problema aparentemente radicaba en el reparo del papa a que el clero castellano fuese gravado a la vez con dos subsidios. Una de las soluciones sugeridas por parte de los embajadores españoles consistía en solicitar la expedición llana del breve de Millones y la ejecución de la décima, con la condición de que el clero de Aragón restituyera integramente al de Castilla este último subsidio. Sin embargo, aunque el breve de restitución representaba cierta transigencia por parte del papa, se incorporó a él una nueva claúsula que vulneraba la regalía inherente a la dignidad real. En virtud de la nueva disposición, el Consejo de Castilla debía reponer los autos que hubiera proveído declarando que los eclesiásticos hacían fuerza oponiéndose a la cobranza de los Millones. 
A estas dificultades se sumaron las instancias que movieron en Roma varios prebendados de Toledo y Sevilla contradiciendo la concesión de dicho servicio y el breve de la décima. Cuando tuvieron noticia de la pretendida revocación, remitieron una copia de la misma a las Iglesias causando graves alteraciones entre los cabildos, que exigieron la celebración de la Congregación. Finalmente, se suprimió la disposición relativa a los procedimientos jurisdiccionales de las causas de Millones. Por lo demás, ninguno de los dos príncipes cedió en sus dictámenes. El breve de Millones mantuvo la inicial claúsula de recomendación. Por su parte, la bula de restitución de la décima fue expedida incorporando la condicional augmentum vero con carácter prescriptible. Pero Felipe IV usó de ambas gracias según los dictamenes de su conciencia. La dificil situación que atravesaban las relaciones Roma-Madrid aconsejaba evitar cualquier manifestación de violencia. El monarca estaba dispuesto a retirar de la Santa Sede a embajadores y cardenales, a prohibir las provisiones de dinero y a despedir a los nuncios. Y por otra parte tenía la firme resolución de cobrar los tributos sin licencia del pontífice. Ante tales amenazas, especialmente las de índole económica, Urbano VIII se vio obligado a ignorar el empleo de los breves así como las formas de exacción utilizadas con el clero.

Los servicios otorgados por el Reino entre 1632 y 1635 , así como los gravámenes impuestos a nuevos artículos y los ensanches aplicados a las especies tradicionalmente sisadas, originaron nuevos motivos de discordia con el clero, que fue obligado a contribuir sin licencia de Su Santidad. Las Iglesias, que estaban reunidas en Madrid, presionaron para que cesase la cobranza de dichas imposiciones. Según afirmaba el Consejo de Castilla, bastaba la mera petición del indulto apostólico para ejecutar la exacción de los 2,5 millones con segura conciencia. Tal actitud de desprecio hacia las inmunidades eclesiásticas no podía por menos que causar la indignación de los clérigos. Resultaba, por tanto, imprescindible obtener la autorización pontificia para evitar escándalos. Sin embargo, la ocasión no se mostraba propicia para reiterar una solicitud semejante cuando estaba pendiente aún la concesión de bula para el servicio de los 2,5 millones. El rey tenía la certeza de que una petición de tal indole sólo podia provocar la denegación de ambos indultos. La necesidad de numerario no permitia aventurar gratuitamente unos efectos que aliviarían las exhaustas arcas de la Hacienda. Por entonces Francia habia iniciado las operaciones para impedir el socorro a Flandes. Por tanto era impensable que el monarca relegara a un segundo plano la defensa de sus Estados en aras de la salvaguardia de las libertades de la Iglesia. Fue el propio clero quien, por medio de la Congregación, ejerció la tutela de sus prerrogativas. Los procuradores comenzaron por enviar a las Iglesias una instrucción para que opusieran resistencia al pago de las sisas. Asimismo instaron al clero prelaticio a colaborar en la conservación de los privilegios del estamento. Por su parte los representantes de los cabildos protagonizaron una intensa labor reivindicativa caracterizada por la dureza de los memoriales elevados al soberano. 
Cuando se crearon los nuevos impuestos para la paga de los 24 millones, los eclesiásticos sumaron un gravamen más en su lista de agravios y comenzaron a proceder contra los corregidores y ministros que entendian en su cobranza, y a publicar censuras contra ellos. En manera alguna podía admitir el clero el dictamen de la Junta que el monarca había mandado formar para la resolución de estos negocios. Según el parecer de dicha comisión, tales imposiciones no eran nuevos tributos "sino suplimiento del servicio de los 19,5 millones, por no ser suficientes las cuatro especies para la paga de ellos. Y que como lo que pagará el clero no excederá de lo concedido por Su Santidad, se puede imponer en otras especies sin breve. $Y$ aun cuando el breve fuese necesario, los grandes gastos de la hacienda permiten que la contribución se continie sin hacer separación bien fiados del breve que concederá el papa o bien con intención de restituir después de lo que se hubiese cobrado indebidamente". El pontífice, como dispensador de los bienes de la Iglesia, había concedido la licencia para la contribución con limitación en el tiempo, en la cantidad y en las especies. Por ello, estimaba la Congregación que la exacción de las nuevas imposiciones exigía un nuevo recurso a Roma. La postura de los cabildos estaba plenamente justificada. Las sisas y otros gravámenes semejantes siempre habían sido consideradas como tributos. Tal carácter explicaba las competencias del Reino en su concesión. Y ello demostraba la carencia de solidez del aserto propuesto por la Junta. En consecuencia, la misma naturaleza de las imposiciones creadas probaba que el derecho de intervención en el otorgamiento de las mismas era común a los estados seglar y eclesiástico.

Por otra parte, la Congregación comenzó a reclamar la inclusión del clero de los otros reinos de la Monarquía en las contribuciones, y a exigir una valuación de las rentas de eclesiásticos y laicos, así como de las cargas que soportaban ambos estados, con objeto de conseguir mayor ecuanimidad en el repartimiento de los tributos. La sustitución del impuesto sobre los tejidos por los nuevos ensanches sobre las cuatro especies no calmó los ánimos de los clérigos ${ }^{18}$. En octubre de 1635 se enviaron instrucciones al marqués de Castel Rodrigo ordenándole que solicitara de Urbano VIII el breve para la contribución del estado eclesiástico en el servicio de los 600.000 ducados. Entre tanto la cobranza se continuaría sin ofrecer refacción.

La aprobación del servicio de los 9 millones creó una situación especialmente difícil. Ninguno de los breves solicitados había sido expedido. Y, por otra parte, los impuestos que se introdujeron para proporcionar a la Hacienda una partida tan importante vulneraban escandalosamente la inmunidad de la Iglesia. Tres de los medios elegidos por el Reino atentaban de manera especial contra las prerrogativas eclesiásticas. En primer lugar, el gravamen establecido sobre las rentas de capital. Se exigía un 5 por 100 de la renta de los juros y censos que se vendieren. Aunque se estableció que dicho porcentaje habían de pagarlo exclusivamente los vendedores, no se previnieron los casos en que el vendedor fuese persona eclesiástica ni tampoco las sucesiones. Tal disposición adolecía de un defecto de forma pues, con harta frecuencia, iglesias, obras pías y personas eclesiásticas adquirían este tipo de 
hacienda en virtud de donaciones testamentarias. La ignorancia premeditada de estos casos tenía como fin último soslayar la impetración de un nuevo breve. En segundo lugar, el donativo impuesto a todos aquellos que tuviesen algún caudal, partida que constituía la aportación más importante para el servicio, y que apuntaba de manera preferente a eclesiásticos, Grandes, consejeros y ministros. Por último, los impuestos sobre los coches, dirigidos a gravar a los sectores más privilegiados de la sociedad.

Las repercusiones derivadas de semejante cúmulo de impuestos indirectos obligaban a buscar al menos cierta apariencia de legitimidad. Era previsible que en todas las ciudades los eclesiásticos intentarían impedir la cobranza de los tributos valiéndose de las armas espirituales. Pero el monarca se mostraba reacio a apelar a Roma. Sabía que el pontífice se había manifestado abiertamente en contra de la concesión de nuevos indultos. Sin embargo, en 1636 se remitieron al embajador en Roma instrucciones para la obtención del breve de los 9 millones y el ensanche de los Millones antiguos; debía advertir al papa que la cobranza de dichos impuestos se estaba efectuando con la promesa de resarcir al clero en caso de que la bula no fuera concedida. Un año después, la congregación de las gracias no había tomado resolución. Según los informes del embajador español, difícilmente toleraría el pontífice que se gravase al clero castellano con más tributos. Puesto que la concesión para el servicio de los 19,5 millones expiraba pocos meses más tarde, parecía más conveniente pedir nueva prorrogación de él.

\section{Los excesos en la cobranza del servicio de Millones (1632-1687)}

Las letras apostólicas que regulaban la concurrencia del clero al régimen de servicios minimizaron el alcance de la obligación establecida por el Reino. Mas limitarse a estimar aisladamente el volumen de la contribución del clero a las cargas comunes que pesaban sobre el estado seglar, sería soslayar dos aspectos esenciales de la institución eclesial durante el Antiguo Régimen. En primer lugar, es preciso considerar la función que desempeñaba la Iglesia en el contexto sociológico de la época. El orden social era considerado resultado directo de la voluntad divina. En consecuencia la inmunidad del clero, amparada por los sólidos fundamentos en los que descansaba, era un principio universalmente aceptado. Ahora bien, a lo largo del siglo XVII los privilegios propios de ciertas categorías sociales entraron en crisis. Las nuevas circunstancias económicas pusieron a los estamentos privilegiados en trance de contribuir a las cargas comunes. No obstante, Nobleza y Clero, en un intento de preservar su rango de signos infamantes, exigieron métodos contributivos que salvaran la ficción legal de su inmunidad ${ }^{19}$. La excesiva frecuencia con que los poderes públicos vulneraban tales principios constituye un excelente indicador de la importancia cualitativa que realmente tuvo la tributación eclesiástica. Por otro lado es menester considerar las demás cargas que el estamento clerical vertía a las bolsas del monarca. La Iglesia, corporativamente, colaboró al sustento de la república con una parte considerable de sus rentas, bien cediéndolas permanentemente a la corona; 
bien transfiriendolas, unas veces quinquenalmente y otras con caracter excepcionals ${ }^{20}$. Por tanto, puede concluirse que el clero castellano contribuyó en gran medida al sostenimiento del Estado.

A partir de 1632, cuando el nuevo sistema físcal está proximo a su configuración definitiva, comenzaron a producirse frecuentes choques entre la potestad real y espiritual, pues ambas mostraron un celo desmedido en la conservación de sus prerrogativas. La imposición de nuevas sisas y arbitrios, así como la inobservancia del breve de los 19,5 millones, cuya publicación fue prohibida por el monarca pretextando que la claúsula augmentum vero convertía al clero castellano en tributario de reinos extraños, originaron los primeros conflictos. Entre 1632 y 1635 fueron muchas las ciudades en las que los Provisores recurrieron a las armas espirituales (censuras, entredichos y cesación a divinis). De todas formas, en ocasiones es preciso cuestionar la justificacion de las protestas del clero. Sobre todo en Andalucia, donde se produjeron los incidentes más ruidosos, las prácticas fraudulentas fueron moneda corriente. En dicha región abundaban los clérigos y religiosos tratantes, para quienes el comercio de vino y aceite eran motivo de lucro. Por otra parte, gran número de tonsurados y de clérigos de "menores" eran arrendatarios de tierras, viñas, olivares y rentas decimales. Estos pretendieron eximirse del pago de sisas, aun sabiendo que tales casos no estaban comprendidos en el indulto de Urbano VIII ${ }^{21}$.

La prorrogación, en 1639 , de los tres servicios básicos -24 . 9 y 2,5 millones, asi como la concesión de otros de menor importancia -8.000 soldados, etc. inauguran una nueva etapa caracterizada por un recrudecimiento de las posturas de la corona y el clero. Las urgencias de la guerra con Francia confirieron un carácter más drástico a las exigencias del monarca. Aunque éste resolvió solicitar breve para la contribución del clero en los servicios de 24 millones y 8.000 soldados, la necesidad de numerario no posibilitaba la espera de las diligencias para obtenerlo. Por ello se dispuso que las sisas habían de correr igualmente para seglares y eclesiásticos. En caso de no obtener la licencia pontificia, el clero sería indemnizado mediante el sistema de refacción. En previsión de posibles alborotos, el monarca inhibia a las Audiencias y Chancillerias del conocimiento de los pleitos tocantes a las causas de Millones, y ordenó a los asistentes, corregidores, jueces y justicias, que debía usarse el remedio de las fiuerzas alli donde los eclesiásticos impidieran la cobranza, remitiéndose los autos al Consejo de Castillas ${ }^{22}$. La Congregación del Clero instó a los cabildos a oponer resistencia a todos los servicios otorgados o que nuevamente se otorgaren si se intentaba cobrar del clero sin breve. Los procuradores no estaban dispuestos a tolerar la reiteración de las vejaciones que, desde 1632 , estaba sufriendo su estamento. Por vez primera se incorporaron a las instrucciones de los Agentes generales capítulos relacionados con los Millones. Se encomendó al Procurador de Madrid el cuidado de los pleitos que fuesen llevados al Consejo por via de fuerza. Asimismo, se le ordenaba mantener correspondencia permanente con el Agente de Roma sobre los negocios relativos a las sisas y otras imposiciones ${ }^{23}$. La 
ferviente defensa de las inmunidades que hicieran ante el pontífice la Congregación y el Procurador de Roma fortaleció la firme decisión de Urbano VIII en orden a no otorgar nuevas licencias contributivas que agravaran la situación económica del clero castellano. Las Iglesias contradijeron tanto el servicio de los 24 millones, como la prorrogación de los 9 y los 2,5, para los cuales ni siquiera se había solicitado bula. Nuevamente Provisores y Vicarios comenzaron a proceder con censuras, excomuniones y entredichos. Pero, sobre todo, es preciso subrayar que, en esta ocasión, la resistencia del clero se extremó. Los fraudes y los disturbios violentos se registraron en torno a tres focos: Andalucía. Extremadura y Salamanca. Los incidentes de este género proliferaron de tal forma que el Consejo de Castilla iuvo que arbitrar medidas que frenaran los excesos del estado eclesiástico. Ordeno a administradores y justicias que elaboraran un registro de los legos que traspasaban propiedades al clero con el propósito de defraudar a la Hacienda. Asimismo dispuso que se cerraran las tabernas de los eclesiásticos que se resistieran a los aforos y al pago de las sisas.

En 1643, Felipe IV, movido por sus escrúpulos, mandó formar la denominada Junta de Conciencia cuya misión consistía en deliberar sobre la rectitud de las nuevas contribuciones, en especial las que atañian al Clero. El rey remitió una circular a todas las Iglesias expresando su voluntad de indemnizar al estamento en razón de todas las sisas impuestas o que de nuevo se impusieren, cuyo pago excediera de la suma de 3.250 .000 ducados anuales. Sin embargo añadia que, a fin de evitar los posibles fraudes, era preciso que seglares y eclesiásticos contribuyeran indistintamente en todos los arbitrios. Al final de cada año los clérigos percibirian la refacción correspondiente. Manifestaba, además, su intención de solicitar breve para los 24 millones que el Reino acababa de conceder. Y para mayor seguridad de du real conciencia, afirmaba que solicitaria tal licencia con suplemento de lo que se habia cobrado desde que expiró la última concesión pontificia (1638). Asimismo impetraría breve para la contribución del estado eclesiástico en las sisas que se habían impuesto después de dicha fecha, con la misma claúsula de composición. En definitiva, el monarca sosegaba su fuero interno, pero en contrapartida el clero se exponía a recibir una nueva lluvia de gravámenes. A pesar de las súplicas del estamento, la bula fue expedida por Inocencio X en 23 de diciembre de 1644 . Además de conceder el servicio, el pontífice condonaba los Millones indebidamente cobrados. Sin embargo, eximia al estado eclesiástico de los 60.000 ducados de renta de juros que el Reino había acordado situar sobre los Millones.Únicamente cedía en mantener inalterable el monto del servicio en que debía contribuir el clero. Aunque el ajuste no satisfizo del todo a las Iglesias, al menos sirvió para poner freno a los alborotos de la década anterior.

La calma no duró mucho tiempo. En 1648 la Congregación comenzó a expresar sus quejas alegando que se continuaban los excesos en la cobranza de Millones. Los cobradores no se ceñian al breve de Inocencio, antes bien, obligaban 
al clero al pago de los demás servicios que había hecho el Reino imponiendo ensanches en las cuatro especies y gravando otras diferentes. Los procuradores del clero reprobaron el incumplimiento de la promesa de refacción que se hizo al estado eclesiástico. Con objeto de asegurar el ajuste de la indemnización la Congregación dilató las concordias del Subsidio y Excusado. Las súplicas al papa por parte del clero se reiteraron con motivo de la escritura de prórroga de los 24 millones (1650). En agosto de ese mismo año el monarca remitía instrucciones al duque del Infantado para que solicitara nueva licencia de contribución. La prorrogación de la gracia, por breve de 23 de octubre de 1650, evitó los roces que, de lo contrario, hubiesen podido esperarse. A pesar de ello, la alteración de la norma contenida en todos los bulas expedidas hasta entonces, mediante la cual se otorgaban facultades a las justicias seglares para tasar las cantidades de los artículos destinados al consumo del clero y sus familias, fue nueva causa de disgustos. El flamante breve ordenaba expresamente a los jueces eclesiásticos la valuación de los productos necesarios para uso del clero. Como contrapartida el monarca expidió una cédula ordenando que ninguna persona pudiera vender los frutos de sus cosechas, ni poner tienda o taberna sin haber aforado y dado primero fianzas, y sin licencia de los administradores o justicias. El incumplimiento de tales requisitos sería penado con el comiso del producto ${ }^{24}$. La cédula suponía un cambio profundo en el sistema de cobranza de los servicios, puesto que al reducir la exacción a la saca y compra de los productos, el tributo recaia sobre el cosechero y el comprador, y no en el consumidor. Por otro lado, las justicias seglares, al erigirse en árbitros de los aforos, incurrían en manifiesta desobediencia a las disposiciones de la Santa Sede.

Para evitar la oposición del estamento era preciso conseguir que el pontífice incluyera nuevos capítulos en el breve de prorrogación. De esta forma se excusarían los fraudes de legos y eclesiásticos, sometiendo al clero a un control más estricto. La Comisión de Millones propuso una serie de medidas encaminadas a incrementar el rendimiento de las sisas. En realidad, lo que con ello pretendia era fabricar un indulto a su medida ${ }^{25}$. Los cambios propuestos iban dirigidos fundamentalmente a incrementar el gravamen de los clérigos que disfrutaban de una posición acomodada. La aplicación de los mismos redundaría en beneficio de la recaudación, pues se evitaría que el clero se excediera en la valuación de los artículos necesarios para su consumo, se reduciría el número de clérigos tratantes. Y lo que era más importante, la colaboración de las jurisdicciones apostólica y real permitiria a los cobradores de Millones actuar con total impunidad a la vez que cesarían las competencias entre ambas potestades. Sin embargo, la Cámara de Castilla no consideró prudente representar al pontífice tales exigencias hasta que el breve de prorrogación no estuviese expedido ${ }^{26}$. Entre tanto el monarca, por cédula de 19 de julio de 1656, ordenó a los eclesiásticos el pago de las sisas, prometiendo refacción en caso de que el pontífice no concediera breve de prorrogación. El propósito último de la corona consistía en ejercer un férreo control sobre el comercio del vino por ser esta especie la que más se prestaba a todo género de engaños y ocultaciones, y por tratarse además del principal artículo que producían y comercializaban los clérigos. En 
segundo lugar, es preciso considerar la repercusión que causó en los círculos eclesiásticos la razón alegada por el monarca para obligar al clero a pagar las sisas valiéndose de la presunta voluntad del pontífice: el elevado número de juros que estaba situado sobre los Millones. Los cabildos estimaron que la corona pretendía convertir al estamento en tributario perpetuo de los juristas que tenian situados sus títulos sobre dichas contribuciones ${ }^{27}$. El rey, con objeto de prevenir los escándalos y embarazos que suscitaría su resolución, remitió cédulas particulares a los prelados ordenándoles la vigilancia de la exacción. Las disposiciones reales y los discursos que, por mandato del soberano, escribieron Antonio de Castro y Andrés de Riaño, causaron una profunda indignación en el ánimo de cabildos y prelados ${ }^{28}$. Aunque la mayor parte del clero prelaticio y catedralicio salió a la defensa de la inmunidad, la oposición de la Iglesia castellana no tuvo un carácter generalizado ni puede calificarse de mancomunada. Mas, es indudable que en el ánimo de los obispos que encabezaron la insumisión existió el propósito de organizar una defensa corporativa de las inmunidades ${ }^{29}$. Los mitrados más prestigiosos opusieron una firme resistencia a la exacción de los tributos. El obispo de Osma, y los arzobispos de Toledo y Sevilla aplicaron su celo al ejercicio de las funciones pastorales desdeñando la obediencia que, en virtud de su condición de miembros del episcopado, debían a la potestad real.

Las primeras manifestaciones explícitas de desacato a la autoridad del monarca fueron obra de la pluma del obispo de Osma. Según la opinión del prelado, las disposiciones de la citada cédula eran contrarias al derecho. Por otra parte señalaba que la bula In Coena Domini castigaba con la excomunion a todos aquellos que imponían y admitían la exacción de tributos al clero sin el consentimiento del pontífices ${ }^{30}$. Por ello, acogiéndose al recurso de contrafuero, suspendió la aplicación del mandato regio y suplicó al monarca el despacho de provisiones y cédulas decretando la suspensión de la cobranza hasta que no llegara el indulto papal. La cédula no respetaba las exenciones puesto que hacía tributario al clero de Castilla sin distinción de bienes, ya fueran éstos espirituales, temporales, eclesiásticos o patrimoniales. Además convertía en pecheras a las personas y cosas consagradas al culto divino. Por otra parte argüía que el tributo del estado eclesiástico se iría prorrogando al compás de las necesidades de la Monarquía. Reparaba asimismo en la desigual consideración que mostraba la corona hacia los estados eclesiástico y seglar. Compelía al clérigo a la contribución, en tanto del lego solicitaba el consentimiento para imponer la carga. Y por último aseguraba que los ministros reales no tenían verdadera voluntad de hacer restitución alguna al clero. La audacia del Cardenal primado aún llegó a más. Recordó al monarca que la estrechez del Erario obligaba a excusar las magnificencias reales. Cuando Moscoso, Palafox y Tapia comenzaron a proceder con censuras y entredichos, los ministros reales temieron que el ejemplo de éstos cundiese entre los demás prelados de Castilla. Comprendieron que el estado eclesiástico fundaba en sólidas razones su repugnancia a los tributos. Era necesario restituir al clero todo cuanto se había cobrado sin breve. Ahora bien, dicha satisfacción sólo incluía los ensanches añadidos a las sisas 
destinadas al pago de los 24 millones, así como los tributos creados para reunir los servicios de quiebras de Millones y 8.000 soldados para cuya cobranza el pontífice nunca había otorgado licencia. Pero jamás se plantearon los ministros la suspensión del nuevo servicio. Es mas, a pesar de que el Consejo de Castilla se inclinaba a seguir una política templada con objeto de atemperar las actitudes de los prelados díscolos, alguno de los miembros de la Cámara aconsejó al monarca el pronto recurso al remedio de la fuerza. Quienes así opinaban prestaban mayor atención al conflicto jurisdiccional subyacente en el fondo de la polémica que al alivio económico que representaban las sisas que el clero se negaba a pagar. Sin embargo, el monarca resolvió usar de los medios suaves que recomendaba el Consejo. Sólo mostró una actitud dura con el obispo de Osma ${ }^{31}$.

Por lo que respecta al resto del episcopado, el soberano optó por remitir a los prelados una nueva cédula en la que daba cuenta de haber ordenado al Consejo la suspensión de las provisiones despachadas. En carta de la misma fecha. Felipe IV proponia al Primado un sistema de refacción fraguado con el ánimo de preservar los intereses económicos de la corona salvando, al mismo tiempo. la ficción legal de inmunidad. La suma procedente de los tributos eclesiásticos se dejaria en depósito a la espera de la determinación del pontífice. Si el breve no era concedido, el monto de la recaudación quedaria a disposición del Ordinario para su posterior distribución entre los interesados. En caso contrario, dicha cantidad se entregaría a los tesoreros y cobradores de Millones. El monarca advertia que el rechazo de la propuesta conllevaba la ejecución de provisiones por parte del Consejo. Pero Sandoval consideró que la aceptación de la restitución exigía la concurrencia de una serie de circunstancias que no se conjugaban. Primero, la imposibilidad de la separación de los dos estados en la cobranza de las sisas. En ningún caso podía aceptar el clero un depósito condicional, indefinido y dependiente de la voluntad ajena. Por otro lado señalaba que no había llegado el caso de extrema necesidad ${ }^{32}$. A raíz de la notificación de la real cédula, el episcopado se vio en trance de tomar partido en el conflicto. Se observa una falta de uniformidad en las posturas de la jerarquia eclesiástica. Pero la diversidad de pareceres no responde exclusivamente a la division de las Iglesias en dos grupos de opinión. La división de criterios es más profunda por cuanto, incluso dentro de una misma diócesis, se registran opiniones divergentes entre el obispo y su cabildo. Sin embargo, de lo que no cabe duda es de que el clero capitular es el sector que se muestra más intransigente.

Los prelados que se negaron a admitir el medio propuesto por el monarca, además de ponderar los mismos argumentos representados por los cardenales Moscoso y Tapia, apoyaron su refutación en una serie de principios canónicos que imposibilitaban la revocación de sus dictámenes. En primer lugar, arguíín que las disposiciones de la bula in Coena Domini impedian alzar las censuras declaradas contra los administradores de Millones porque la absolución de las mismas estaba reservada a la Santa Sede. De otro lado, señalaban las limitaciones de la jurisdicción episcopal, carente de facultades para compeler al cabildo y clero de su diócesis a 
contribuir en los tributos en contra de su voluntad, pues aseguraban que sólo la suprema potestad del pontífice podía dispensar del privilegio de exención. El clero estaba resuelto a no ceder en sus dictámenes. La corona se encontraba ante la disyuntiva de iniciar una lucha jurisdiccional de perniciosas consecuencias o buscar un arreglo que le permitiera aliviar sus necesidades de numerario y fortalecer su potestad. Era necesario encontrar una fórmula que permitiera a la vez satisfacer ai clero y mantenerlo sujeto a las exigencias de la corona. Puesto que el episcopado no se oponia a admitir medios de refacción justos, el Consejo no tuvo más remedio que comenzar a perfilar la concordia definitiva. Se ofreció satisfacción de todos los tributos que había pagado el clero desde que se iniciara la exacción del nuevo servicio de 24 millones. El cálculo de las sumas a restituir se efectuaria con separación de las especies gravadas, evaluando el expendio de las mismas por ciudades, villas y lugares. Posteriormente, se procederia a realizar una estimación de las cantidades que cada clérigo hubiese podido consumir, estableciendo como punto de referencia el número de vecinos de cada lugar. La labor que requerían las liquidaciones era tan minuciosa que el Consejo tenía el convencimiento de que la licencia llegaría antes de que el clero pudiera percibir la indemnización. El cómputo sería efectuado conjuntamente por los administradores de Millones y las personas que designara el estado eclesiástico. La forma y los plazos de pago se dejaban al arbitrio de los prelados. La cantidad a restituir era inferior a la décima parte del valor de los servicios, puesto que quedaban excluidos de la refacción los productos que el clero obtenía libres de sisa. A mediados de junio se ajustaba escritura de concordia entre el cardenal Moscoso y el cabildo de Toledo con el administrador de los servicios de dicha ciudad, y con Gerónimo Sanvitores, consejero de Hacienda y miembro de la Comisión de Millones. En dicha escritura se estipulaba que los clérigos cosecheros habian de hacer declaracion del volumen de sus cosechas, asi como de la cantidad de productos que hubieren vendido por mayor y por menor, ante los jueces eclesiásticos. La tasación del gasto de las labores y familias del estamento quedaba a cargo de los mismos jueces, debiéndose efectuar en presencia del ministro de Millones de cada lugar. Los vicarios y administradores generales se obligaban a dar al clero, libres de sisas, las porciones de carne necesarias para su consumo en aquellos lugares donde la escasez de eclesiásticos constituyese una garantía contra los fraudes. Ahora bien, los reparos que la Comisión de Millones hizo a algunos capítulos de la concordia determinaron la expedición de una real cédula por la que se introducian nuevas claúsulas de ajuste y se alteraban las anteriormente asentadas. Las declaraciones de los eclesiásticos cosecheros eran sustituidas por el registro y aforo de sus bodegas, almacenes y cosechas. Tales operaciones correrían a cargo de los jueces eclesiásticos, pero se efectuarían con la asistencia de los ministros reales. A fin de evitar fraudes y usurpaciones, los clérigos recibirían de las justicias seglares guías y licencias para sacar y vender sus productos. El cómputo de los eclesiásticos residentes en cada ciudad, así como la tasación del consumo de sus familias, se realizaría conjuntamente por los ministros seglares y los jueces eclesiásticos. Se especificaba además que de la refacción correspondiente a los géneros comprados por menor, se bajaría el importe de lo que el clero introducía por mayor libre de 
derechos. Por último se añadía que se procedería contra los clérigos tratantes y compradores conforme al Derecho y los Sagrados Cánones.

Además la cédula contenía declaraciones contrarias a la inmunidad, trataba a los prelados de sediciosos y perturbadores de la quietud pública, y menospreciaba la jurisdicción eclesiástica. El clero no podía admitir semejante cédula. Y mucho menos, aceptar una escritura mediante la cual se pretendía establecer y perpetuar el principio de que el estado eclesiástico podía ser compelido al pago de las sisas sin el oportuno indulto papal. Finalmente, el monarca accedió a despachar una nueva cédula conforme con el primer ajustamiento que el clero carpetano hiciera con sus ministros. Otros prelados se mostraron dispuestos a otorgar escritura de concordia en los mismos términos que la ajustada por el arzobispo de Toledo. Sin embargo, la refacción no tuvo efecto, pues a fines del mismo año Alejandro VII otorgaba el ansiado breve ${ }^{33}$.

E1 corto pontificado de Clemente IX fue aciago para el estamento eclesiástico de Castilla. En 1668, este pontífice no sólo prorrogó el breve para la contribución del clero en el servicio de los 19,5 millones, sino que expidió una nueva bula que permitía a la corona compeler al clero al pago de otros servicios otorgados por el Reino. A saber: 2,5 millones, 8000 soldados, 2 millones de quiebras y 6 millones. En total una suma aproximada de 12.300 .000 ducados anuales durante un sexenio. A fines de febrero de 1669 , la regente notificaba a todos los prelados del reino las concesiones pontificias, encargándoles la contención de los posibles escollos que el clero pondría a la ejecución de las letras apostólicas. La cobranza de los nuevos tributos conmocionó a todo el estado eclesiástico. La ejecución del indulto pontificio suponia en la práctica, además de un aumento considerable de los tributos que soportaba el clero, la anulación de sus privilegios fiscales y, en consecuencia, la ignominiosa equiparación contributiva de los estados seglar y eclesiástico. Asimismo reprobaron las Iglesias la innovación que contenia la bula. Una de sus claúsulas establecia ía exención de todos los productos necesarios para el consumo de los clérigos cuando dichos artículos procedieran de rentas propias o de limosnas destinadas al culto divino. Ello suponía la relevación de los eclesiásticos cosecheros y el agravamiento de las cargas que pesaban sobre los sectores menos favorecidos del estamento. Consecuentemente, el clero alegó que el breve atentaba en contra de la justicia distributiva. Cuando los corregidores comenzaron a proveer autos ordenando la suspensión de la refacción que se daba a los clérigos en las carnicerías y pescaderías, los Provisores y Vicarios procedieron a fulminar censuras. Cabildos y prelados remitieron memoriales a Mariana de Austria suplicando la supresión de la cobranza. La Iglesia de Toledo, en nombre del estamento, advirtió a la reina su disposición para enviar a Roma prebendados que representasen al papa la imposibilidad del clero para contribuir en los nuevos servicios. El cabildo hizo hincapié en los defectos formales del breve que, en su opinión, carecía de fuerza coactiva pues los ministros reales se habían valido de los vicios de obrepción y subrepción para ganar el indulto, refiriendo con siniestra relación los aprietos de la 
corona y ocultando el gran número de gravámenes que soportaba el estado eclesiástico de Castilla. Por otra parte, las Iglesias subrayaron las pésimas consecuencias que para la Hacienda tendrían los capítulos referentes a los eclesiásticos más ricos. Los clérigos, y especialmente las comunidades, buscarían la forma de hacerse cosecheros, negociadores y tratantes de las especies gravadas. Por último, se quejaba el clero de quedar obligado a concurrir con los legos en los servicios que éstos otorgaban.

La oposición del estamento eclesiástico suscitó una división de pareceres en el seno del Consejo de Castilla. En tanto la mayor parte de sus miembros se inclinaba por continuar la ejecución del breve y estimaba conveniente que la reina ordenara a los prelados procurasen contener a sus cabildos en la resistencia que alentaban entre el clero y las religiones, algunos consejeros opinaban que era preciso excusar resoluciones extremas y limitarse a usar de lenitivos. Aconsejaron a la soberana que recurriese al cardenal Aragón para que intentara vencer la resistencia de su cabildo pues, una vez superado este escollo, podía esperarse que las demás Iglesias siguieran el ejemplo de la Primada. Pero advertían que si el cabildo de Toledo persistía en su dictamen no habría más remedio que sobreseer el uso de la concesión, porque lo contrario sería arriesgar la cobranza de los 19,5 millones. Dos meses después, por real cédula de 26 de julio de 1669 , la reina suspendía definitivamente la ejecución del breve de los 12.300 .000 ducados $^{34}$.

La debilidad e inestabilidad política que caracterizó el reinado de Carlos II, asi como la recesión económica que sufrió Castilla ente 1677 y 1687 constituyeron una coyuntura favorable para que el estado eclesiástico recuperara parte de su poder. Desde los primeros años de la Minoría del monarca, el clero -y de manera especial la Iglesia de Toledo- inició una lenta recuperación de su capacidad de presión. A partir de los años setenta la corona se vio entrance de renunciar a cantidades crecientes de las sumas concedidas por la Santa Sede, otorgando al estamento eclesiástico rebajas considerables en los distintos indultos ${ }^{35}$. Con posterioridad a la crisis de 1669. los pontífices habían continuado otorgando breves para que el clero contribuyera en el servicio de los 19,5 millones que las ciudades de voto en Cortes habían renovado en 1673 y 1679. En 1685 se prorrogó dicha concesión. Ese mismo año el agente real iniciaba en Roma las diligencias para obtener la licencia papal. En julio del siguiente año -próximo a cumplir el plazo de contribución fijado en el breve anterior- Ia corona encargaba al Consejo de Castilla la búsqueda de fórmulas que permitieran continuar la cobranza de las sisas en tanto el pontífice se decidía a expedir una nueva bula. Dada la efervescencia que experimentaba la resistencia del clero a la presión fiscal, era impensable mantener la exacción de los Millones menospreciando abiertamente la inmunidad de la Iglesia. Por ello, el monarca ordenó a los administradores del servicio que convinieran con los prelados y cabildos un medio de refacción, y posteriormente procedió a notificar a los prelados su resolución. La negativa del estamento eclesiástico, dirigido por el cardenal Portocarrero, a aceptar el ajuste amenazaba con provocar una crisis semejante a la 
que habia tenido lugar treinta años atrás. Durante el verano de 1686 se llevaron a cabo las negociaciones con el Primado. Simultáneamente, en Roma, el Procurador general del clero libraba su batalla particular con el agente real. La restitución ofrecida a las Iglesias era una copia fiel de la que se arbitro en 1656. Pero el Primado no depuso su actitud y comenzó a fulminar censuras contra los ministros de Millones. A comienzos de octubre el monarca comunicaba al cardenal que, en adelante. los eclesiásticos recibirian las especies gravadas libres de sisas y se restituiría a los clérigos las cantidades que hasta entonces habian pagado. Pero, una vez más. la refacción no tuvo efecto porque, en 22 de enero de 1687, Inocencio XI despachó el breve de prorrogación de los 19,5 millones.

\section{El estamento eclesiástico ante los servicios de Millones}

La primera vez que el Reino solicitó de forma explícita la contribución del estado eclesiástico en los servicios de Millones fue en 1626. Ahora bien, según se demostraría poco después, la fórmula empleada daría pábulo a las Iglesias para oponer resistencia al pago de las sisas, por cuanto aquellas consideraron que su contribución a las cargas públicas únicamente podía ser ordenada y regulada por la Sede Apostólica. El dilatado conflicto que se suscito a raíz de las peculiares claúsulas restrictivas que contenía el breve de 5 de marzo de 1632 incidio en el cambio de signo que experimentó la formulación del Reino pocos años después. En virtud de la nueva disposición el clero quedaba sujeto al pago de las contribuciones por el mismo título que el resto de la población. Esta fórmula permanecerá vigente durante todo el $\operatorname{siglo}^{36}$. Desde entonces, aunque la corona continuó solicitando de la Santa Sede las bulas de contribución, en la práctica la tributación del estado eclesiástico, más que por los indultos papales, estuvo regulada por la conciencia de los monarcas y por los dictámenes de sus ministros. Los Austrias despojaron al clero de sus privilegios fiscales invocando la penuria del estado seglar y las urgentes necesidades de la Monarquia para compeler a los eclesiảsticos al pago de íos servicios, fiados en la presunta voluntad del pontifice. Por su parte, las Iglesias exigieron la estricta observancia de los breves. Las licencias pontificias permitian exclusivamente la contribución de dicho estamento en los servicios originarios. Primero en los 12 y los 18 millones. Más tarde -cuando se unieron los dos anterioresen los 19,5 millones. Además limitaban el número de especies e impuestos que podían exigirse al clero. Al principio, vino, vinagre, aceite y carnes. Posteriormente, los pontífices ampliaron el alcance de sus indultos extendiendo la contribución al pago de algunos ensanches cargados sobre dichas especies, al jabón y a las velas. Pero en esencia, las cláusulas de los breves permanecieron inmutables durante toda la centuria. En general, el contenido de las mismas no difiere de lo estipulado en los indultos otorgados para otro tipo de gracias. Se fijaba un período contributivo coincidente con el plazo establecido por el Reino para la recaudación del servicio. Una vez fenecido el sexenio, cesaba la obligación, independientemente de que la suma ofrecida por las Cortes se hubiese reunido. Se prevenia también la suspensión 
de la cobranza en aquellos casos en los que el rendimiento de las sisas permitiera hacer frente a la cantidad acordada por el Reino antes de que expirase el plazo establecido. Asimismo se hacía relación del tifo de productos exentos de las imposiciones, y se declaraba la jurisdicción competente para compeler a los eclesiásticos al pago de las sisas y otros tributos.

El verdadero motivo de la tenaz resistencia del estamento fue la continua inobsevancia de los breves. Sólo cuando la presión fiscal se hizo insoportable para todos, cabildos y prelados alegarán de forma sistemática una nueva queja: la injusticia inherente a un sistema impositivo que permitía sujetar al estado eclesiástico al pago de servicios otorgados con la sola voluntad del Reino.

Por lo que respecta a la baraja de contribuciones eclesiasticas, los Millones son la figura fiscal que mas vejaciones infiere a los privilegios de la Iglesia y la que con mayor frecuencia vulnera las disposiciones pontificias. En la mayoria de los casos esta imposición comienza a exigirse sin que preceda la correspondiente licencia papal. Las refacciones se ofrecen con el único fin de evitar escándalos e inconvenientes, sin que exista verdadera voluntad de restituir. Además, muchas de las clausulas se infringian de manera sistemática. Así las relativas al período y cantidad de la contribución; las que declaraban la incompetencia de la jurisdicción seglar para compeler al clero a la paga de las sisas; y aquellas que determinaban la exención de determinados productos. Durante el siglo XVII, el clero hubo de contribuir en crecimientos y especies que no estaban contenidos en los breves. El organismo que ejercia la representación de dicho estamento carecía de poder para preservar su inmunidad de los excesos que los ministros seglares cometían en la cobranza de los Millones. La Congregación tampoco pudo ajustar con la corona una concordia semejante a la del Excusado. Por tanto, su capacidad de negociación fue nula. El nacimiento de la fiscalidad del Reino infirió un golpe mortal a los privilegios de la Iglesia. Al quedar los clérigos sujetos a las nuevas imposiciones como los demás vasallos de la corona, las Iglesias perdieron la posibilidad de manipular a su favor las aportaciones del estado eclesiástico a los Millones. Las nuevas figuras fiscales no gravaban al clero corporativamente ni eran administradas como las Tres Gracias- por un Consejo que gozaba de jurisdicción espiritual privativa, delegada de los pontífices ${ }^{37}$. En consecuencia, los cabildos se vieron obligados a solicitar la ayuda de los prelados para contener los excesos de los jueces seglares pues, en definitiva, la tutela de las prerrogativas eclesiásticas tocaba a los Ordinarios, tanto por ser ésta una función inherente a su ministerio como porque la Santa Sede delegó en ellos la vigilancia del recto cumplimiento de sus indultos.

La Congregación se limitaba a denunciar los excesos de los ministros seglares y a elevar memoriales solicitando que el clero no fuese gravado con aquellas imposiciones que no estaban contempladas en las bulas. Ahora bien, en virtud de su naturaleza corporativa, disponia de la autoridad necesaria para armonizar las diligencias que, en materia de Millones, debían seguir los cabildos. Con objeto de 
prevenir posibles irregularidades advertía a las Iglesias la forma de ejecución de los breves. El procedimiento era el siguiente. El deán y el cabildo de cada Iglesia debían entregar al obispo un traslado autorizado del indulto. A requerimiento del capítulo, el Ordinario aceptaba formalmente la jurisdicción delegada del pontífice. Y a continuación subdelegaba en su Provisor, quien procedía al despacho de mandamientos ordenando a las justicias seglares la observancia del breve, y comisionaba a arciprestes, vicarios y demás jueces eclesiásticos la tutela del mismo. También se notificaba la licencia papal al Fiscal eclesiástico pues a él correspondía, en definitiva, la defensa de la inmunidad. La Congregación advertía a los jueces eclesiásticos que debían excusar los pleitos injustos y evitar los fraudes. Asimismo insistía en que era imprescindible el mandato del Ordinario para proceder a los registros y aforos de las bodegas y almacenes del clero.

La Congregación solía enviar instrucciones a las Iglesias ordenado las diligencias pertinentes para evitar que los ministros reales compelieran a los eclesiásticos al pago de las sisas una vez fenecido el período contributivo. Un día antes de que expirase el sexenio, los provisores habian de requerir con un traslado autorizado del breve de concesión a los cobradores, jueces y diputados de Millones, advirtiendo que había cesado la obligación del clero. Si dichos ministros proseguían la cobranza, los eclesiásticos procederian a querellarse ante el Ordinario. El requerimiento lo hacían los fiscales, el cabildo o el Procurador general, informando al obispo de la contravención. Una vez que el Ordinario declaraba que el delito era contrario a las disposiciones de la bula In Coena Domini, los provisores estaban obligados a publicar las excomuniones y a proceder contra los ministros hasta recurrir a los últimos remedios del derecho -entredicho y cesación a divinis-. Pero la Congregación advertía que debía evitarse, en la medida de lo posible, que los provisores actuaran como jueces de este tipo de causas. Era preciso que los obispos avocaran a sí dichos pleitos. La gravedad de los procedimientos eclesiásticos sólo se manifestaba en toda su extensión si las libertades de la Iglesia eran defendidas por los verdaderos jueces competentes, pues ellos actuaban en virtud de una jurisdicción recibida directamente del pontífice. En el fondo, lo que la Congregación pretenđía evitar era que el Consejo de Castilla menospreciara la suprema potestad espiritual, lo que sucedia con frecuencia cuando el obispo subdelegaba sus competencias. Una vez fulminadas las censuras, el Consejo despachaba provisiones de ruego para que los prelados absolviesen a los incursos. Dicha apelación no podía tener efecto suspensivo porque los Ordinarios actuaban como meros ejecutores de la Bula de la Cena, en virtud de la cual la absolución quedaba reservada al papa. Los obispos se limitaban a otorgar el devolutivo, es decir, a restablecer al reo al estado anterior a la declaración de las penas espirituales por un tiempo competente. Si los tribunales reales recurrian al remedio de las fuerzas, los fiscales eclesiásticos o, en su caso, los cabildos apelarían al pontífice.

Por lo que respecta a la prevención de fraudes, eran los propios Ordinarios quienes arbitraban en sus respectivas diócesis las medidas oportunas con objeto de 
reparar los dolos de seculares y regulares. Todos los prelados estaban de acuerdo en que los artículos destinados al consumo del clero debian estar exentos de imposición, pero coincidían también en señalar que los productos destinados a la comercialización estaban sujetos al pago de tributos. Con frecuencia, religiosos y clérigos se sustraían al pago de las sisas. Pero se observa una clara diferencia en las conductas del clero secular y regular. Las acusaciones que recaen sobre el primero refieren tres tipos de delitos. El más frecuente consistía en eludir los tributos debidos en razón de sus bienes particulares mediante la venta de sus cosechas en sus propias casas. Dicha actividad estaba contemplada por las leyes canónicas. Ahora bien, los eclesiásticos no se conformaban con no pagar, sino que cobraban para sí la sisa de los artículos que vendían. Pero eran muchos los seglares que se acogían al fuero de la Iglesia con el ánimo de sustraer sus bienes al fisco. Las ordenaciones "de menores" y la fundación de capellanías eran las fórmulas más comunes de sustraer a la imposición los bienes familiares, aunque también abundaban quienes ponian su hacienda en cabeza de eclesiásticos. En cambio, las quejas sobre la conducta del clero regular versaban sobre la venta clandestina, sin sisa, de productos de primera necesidad en el interior del convento. A veces también usurpaban a la Hacienda los derechos que dejaban pagados quienes compraban los productos que expendían. Las instrucciones de los Ordinarios prevenían el castigo de tratos y granjerías, prácticas que estaban prohibidas por los Sagrados Cánones. Algunos eclesiásticos arrendaban viñas, olivares y diezmos; e incluso compraban uva o mosto para elaborar caldos que destinaban a la comercialización. Y con el pretexto de que tales productos procedían de los bienes que poseian a título de heredad, pretendían eludir el pago de las sisas.

Conforme fue arreciando la presión tributaria y la crisis económica, los fraudes se hicieron más frecuentes. Sobre todo en la segunda mitad de la centuria, a medida que el poder civil se iba debilitando, la defraudación fue convirtiéndose en una práctica generalizada. Los abusos se perpetraban en todas partes, pero con mayor exceso y frecuencia en Andalucía, región que sobrepujaba por su alto grado de actividad económica y comercialización agrícola. Con objeto de evitar las prácticas fraudulentas, desde 1639, la corona ordenó el registro y aforo de los frutos pertenecientes a los exentos. Sin embargo, no sólo no cesaron los fraudes sino que, en muchos lugares, el clero se resistió a los registros. Para el mejor cobro y administración de la renta de Millones, el monarca ordenó la ley general de 28 de diciembre de 1654 , por la cual disponía que los abastos sólo podrían abrirse con licencia de la justicia seglar, previo aforo de los frutos de sus dueños y pago de las sisas. Pero ninguna de las medidas arbitradas por el poder civil bastó para detener las prácticas fraudulentas. Las sanciones con que se castigaba a los eclesiásticos defraudadores no eran severas. Las penas no iban más allá del destierro o la simple amonestación. De una u otra forma, el clero continuó resistiéndose al aforo de sus cosechas amparándose en su fuero para defender sus intereses materiales ${ }^{38}$.

Las perniciosas consecuencias de los servicios de Millones, así como la repugnancia que dichas imposiciones suscitaban entre seglares y eclesiásticos, se 
reflejan en multitud de escritos. Era notorio que estas contribuciones gravaban fundamentalmente a los pobres, es decir, a aquéllos que no tenían cosechas ni posibilidad de comprar por mayor; que los poderosos, ya fueran seglares o eclesiásticos, se valían de todo tipo de artes y cautelas para defraudar a la Hacienda; que la administración y cobranza de los servicios era infinitamente más gravosa que la propia imposición. Pero también se reprochaba, en ocasiones, la creciente importancia de las ciudades de voto en Cortes, que actuaban como "dueñas de los intereses y bien público del Reino". De lo cual resultaba la penosa sujeción del clero a los procuradores seglares pues, según expresaba uno de estos alegatos, los ministros reales sometían con facilidad la voluntad de los prelados. 


\section{NOTAS}

1.- CARPINTERO AGUADO, L. La Congregación del Clero de Castilla en el siglo Xriti, tesis doctoral incdita. Madrid, Universidad Autónoma, 1993.

2.- Indulgencias que junto con la Cruzada se conocen con el nombre de "las Tres Gracias".

3.- ARTOlA GAllego. M. La Hacienda del Antiguo Régimen. Madrid, 1982, pág. 91.

4.- Ibidem, págs. 120-122: ULLOA, M. La Hacienda Real de Castilla en el reinado de Felipe II. Madrid. 1977. paigs. $510-511$.

5.- Veáse nuestra tesis doctoral, págs. 306-307.

6.- ARTOL.A. M. Op. cit., págs. 128-130.

7.- Breve de Clemente VIII en que, ratificando las concesiones antecedentes, para que concurran los Eclesiásticos en la contribución de Millones, establecida sobre el vino, aceite y carnes, la extiende al vinagre y aguapié, 17 de diciembre de 1604.

8- ARTOLA, M. Op. cit., págs. 112-113.

9.- Breves de 31 de mayo de 1628 y 29 de mayo de 1629. La introducción del servicio de los 12 millones determinó la creación de nuevos impuestos (Veảse ARTOLA, M. Op. cit., pág. 130).

10.- ARTOLA, M. Op. cit. págs. 98-103.

11.- El propio Lirbano VIIl manifesto a Felipe IV la repugnancia que ie causaba el procedimiento por el que se imponian los millones: "... vemos que para valerse V.M. del Servicto y donatro de millones ha procurado el consentiniento y veneplazto de sus Vasallos por medio de los Procuradores de las Ziudades de esos Reynos. aue muchos no le han dado y si no le tuviera de la mayor parte ni se repartieran ni cobraran de los dichos Vasallos. siéndole súbditos, y tan ynmediatos por donde es caso duríssimo que para haver de repartir estos mismos millones, sobre los bienes de las Yglesias, y eclesiásticos que por derecho divino son tan exemptos como está dicho se haya de hazer esto sin el consentimiento de ellos, y sin consultar los Capitulos de las Yglesias, contra expreso tenor de los Sagrados Cánones, tratandolos en esto con tanta desigualdad, y sin usar con ellos, siquiera el mismo término que con los Seglares. caso claro y desigualdad grande que el consentimiento de los Vasallos Seglares aya de bastar para comprehender a los eclesiasticos y que un mismo tributo ayy de ser comun, a los unos y los otros tratandolos peor. que el mismo estado de la republica...".

12.- El propio Urbano VIII manifestó a Felipe IV la repugnancia que le causaba ei procedimiento por el que se imponían los millones: ".. vemos que para valerse V.M. del Servicio y donativo de millones ha procurado el consentiniento y veneplazito de sus Vasallos por medio de los Procuradores de las Ziudacies de esos Reynos, que muchos no le han dado y si no le tuviera de la mayor parte nt se repartieran ni cobraran de los dichos Vasallos, siéndole súbditos, y tan ynmediatos por donde es caso durtssimo que para haver de repartir estos mismos nillones, sobre los bienes de las Yglesias, y eclesiásticos que por derecho divino son tan exemptos como está dicho se haya de hazer esto sin el consentimiento de ellos, y sin consultar los Capítulos de las Yglesias, contra expreso tenor de los Sagrados Cánones, tratandolos en esto con tanta desigualdad, y sin usar con ellos, siquiera el mismo término que con los Seglares, caso claro y desigualdad grande que el consentimiento de los Vasallos Seglares âya de bastar para 
comprehender â los eclesiasticos y que un mismo tributo âya de ser comun, a los unos y los otros tratandolos peor, que el mismo estado de la republica...".

13.- DOMinguez ORTiZ, A. Política y Hacienda de Felipe $I V$, Madrid, 1983, págs. 42-47.

14.- Un estudio profundo sobre la crisis de las relaciones Iglesia-Estado en la década de los treinta en ALDEA VAQUERO, Q. Iglesia y Estado en la España del siglo XVII, Comillas, 1961.

15.- Veáse nuestra tesis doctoral, pág. 316.

16.- Según apuntan ARTOLA, M. Op. cit., pág. 131; y DOMiNGUEZ ORTIZ, A. Politica y Hacienda, págs. 225-226, cuando se renunció a la reforma fiscal mediante la cual pretendieron suprimirse los Millones, el Reino mantuvo para la sal un precio lo suficientemente alto para que produjese 750.000 ducados de los 4 millones que se pagarían anualmente. Esta cifra se obtuvo finalmente de los nuevos recargos que se establecieron sobre los artículos de consumo ya gravados por las sisas. Esta misma observación la hace el Consejo de Castilla en consulta de 5 de octubre de 1638 .

17.- Un análisis de esta contribución extraordinaria en nuestra tesis doctoral, págs. 360-365.

18.- Con el fin de reunir la ayuda de los 600.000 ducados se creó un impuesto sobre los tejidos: la sisa del medio dozavo de la vara de medir.

19.- DOMINGUEZ ORTIZ, A. "La desigualdad contributiva en Castilla durante el siglo XVII", Anuario de Historia del Derecho Español, (1951-1952), págs. 1223-1225.

20.- Veáse nuestra tesis doctoral, págs. 86-114, 208-298 y 360-391.

21.- El breve de 5 de marzo de 1633 establecía el alcance de la contribución en los siguientes términos: "Decretamos que todas y cualesquier personas eclesiásticas asi Seculares como Regulares de cualquier orden, aun exenta e inmediatamente sujeta a la Sede Apostólica, y los monasterios de hombres y mujeres. conventos y colegios, cabildos de las Iglesias de Castilla y León estantes y habitantes en los dichos Reinos, estén obligados a pagar y contribuir con los seglares en el dicho subsidio de 19,5 millones de escudos mediante la paga de las sisas puestas sobre el vino, vinagre, aceite y carne que se cogieren y consumieren en los dichos Reinos durante los 6 años desde el primero de agosto de 1632, tan solamente las dichas cuatro especies de cosas que cobran y sacan por si o por otras personas o por sus arrendatarios de sus propias tierras o de diezmos, o de otras cualesquier rentas propias, o de limosnas y que gastan para el culto divino, o para uso propio o de sus familias, en razón de lo cual queden del todo inmunes $y$ exentos".

22.- Un análisis sobre las cuestiones jurisdiccionales en nuestra tesis docioral, págs. 163-172.

23.- Una visión sobre el perfil institucional de las asambleas y la figura de los Agentes Generales, Ibidem, págs. $31-74$.

24.- La cédula fue expedida en 28 de diciembre de 1654 , y confirmada posteriormente por otra de 10 de enero de 1655 .

25.- Según ARTOLA, Op. cit., pág. 115, al mismo tiempo (1635) que los servicios se convierten en una carga permanente, se produce un trasvase del control fiscal a manos del Reino o más precisamente de su Comisión de Millones. El mismo autor (Op. cit., págs. 137-138) señala que en 1658 se produjo la definitiva incorporación de la citada Comisión al Consejo de Hacienda, medida que significó una mediatización de la institución por la administración. Este proceso anticipó la transformación práctíca del servicio de Millones en un impuesto de la Corona. 
26.- Una relación de las medidas propuestas por la Comisión de Millones en nuestra tesis doctoral, pág. 336.

27.- En relación al tema de los juros, veáse nuestra tesis doctoral, págs. 278-285.

28.- Veáse nuestra tesis doctoral, pảgs. 199-200.

29.- Ibidem, págs. 338-339.

30.- Ibidem, págs. 185-186.

31.- Ibidem, pág. 341 .

32.- Ibidem, pảg. 342. Cédula de 28 de enero de 1657; Carta de Felipe IV al cardenal Sandoval; Carta de Moscoso y Sandoval en la que responde a la cédula anterior.

33.- Cédula despachada en 31 de septiembre de 1657.

34.- Veáse nuestra tesis doctoral, págs. 348-350.

35.- Ibidem, págs. 258-271 y 361-363.

36.- Ambas förmulas en ARTOLA, M. Op. cit. pág. 107, not. 1, y pág. 108.

37.- Veáse nuestra tesis doctoral, págs. 149-173.

38.- Sobre los incidentes derivados de las prácticas fraudulentas, Ibidem, pág. 357, not. 129, y pág. 358. 